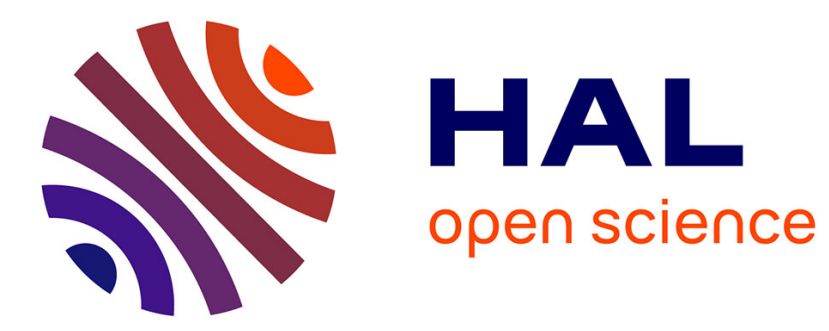

\title{
Move or change, an eco-evolutionary dilemma: the case of Collembola
}

\author{
Jean-François Ponge
}

\section{To cite this version:}

Jean-François Ponge. Move or change, an eco-evolutionary dilemma: the case of Collembola. Pedobiologia, 2020, 79, pp.150625. 10.1016/j.pedobi.2020.150625 . hal-02482688

\section{HAL Id: hal-02482688 \\ https://hal.science/hal-02482688}

Submitted on 18 Feb 2020

HAL is a multi-disciplinary open access archive for the deposit and dissemination of scientific research documents, whether they are published or not. The documents may come from teaching and research institutions in France or abroad, or from public or private research centers.
L'archive ouverte pluridisciplinaire HAL, est destinée au dépôt et à la diffusion de documents scientifiques de niveau recherche, publiés ou non, émanant des établissements d'enseignement et de recherche français ou étrangers, des laboratoires publics ou privés. 


\section{Move or change, an eco-evolutionary dilemma: the case of Collembola}

2 Jean-François Ponge*

Abstract

The present opinion paper suggests that springtails, which can live above- and/or belowground according to species requirements, have two strategies at their disposal to face environmental hazards, called 'move' or 'change'. Species with poor dispersal capacity, often parthenogenetic, and living mainly in a confined environment, have to adapt themselves by increasing their phenotypic plasticity or letting the environment selecting or adding favourable mutations. Conversely, species with a high dispersal capacity, often sexual and living in a more open environment, may emigrate and immigrate without the need to become better adapted to changing environmental conditions. Advantages and disadvantages of these two tactics are reviewed and their prospective responses to global changes are compared on the light of existing knowledge on this microarthropod group.

\section{Keywords}

Collembola Movement Dispersal Adaptation Evolution Strategy

\section{Introduction}

It may seem at first sight surprising that some living forms crossed geological ages without any pronounced changes in their appearance while others diverged to a great extent (Gould and Eldredge 1993). Examples of the former are 'living fossils', as the coelacanth (Amemiya et al. 2013) and the wollemi pine (McLoughlin and Vajda 2005). Both of them are still living in stable and concealed marine and terrestrial environments, respectively, which offered them some unexpected protection until they became endangered in their original niches by the ineluctable growing impact of human activities in the Anthropocene (Dirzo et al. 2014). Let us highlight the case of springtails (Collembola), known from the Early Devonian, ca. 400 Ma ago (Scourfield 1940, Greenslade and Whalley 1986), and present in terrestrial environments as diverse, modern species assemblages as soon as the Early Cretaceous, ca. 110 Ma ago (Sánchez-García and Engel 2017, Sánchez-García et al. 2018). Palaeozoic families have seemingly crossed the Cretaceous-Paleogene (K-Pg) mass extinction, which devastated the global environment and destroyed three quarters of plant and animal species on

\footnotetext{
*J.F. Ponge Muséum National d'Histoire Naturelle, CNRS UMR 7179, 4 avenue du Petit Château, 91800, France Tel.: +33 (0)678930133 email: ponge@mnhn.fr
} 
Earth ca. 66 Ma ago. Christiansen and Pike (2002) evoked a taxonomic turnover at genera level while other authors support the idea that most present-day genera crossed the crisis (Richards 1968, Hädicke et al. 2013). These tiny arthropods are worldwide spread and live in various environments as soil (from litter to deep soil), vegetation (from lichen and moss carpets to tree crowns), ponds, salt marshes, deserts, glaciers (Hopkin 1997). However, the species composition of their communities differ at large-scale among continents and islands because of geographic isolation (Shaw et al. 2013), and at small-scale among micro-habitats because of adaptive specialization (Salmon and Ponge 2012). In heterogeneous landscapes under the influence of human activities a deficit of recolonization (ecological debt) is known to affect species moving more slowly, pointing to the importance of dispersal for the survival of collembolan species in a changing environment (Ponge et al. 2006). This urges us to question the strategies by which Collembola survived past ecological crises: will they allow them surviving (or not) the ongoing sixth mass extinction (Barnosky et al. 2011)? In an appealing paper Berg et al. (2010) stressed the importance of a good knowledge of biotic interactions and functional traits linked to adaptation and dispersal if we want to predict the fate of species in a global change perspective. In a recent paper Thompson and Fronhofer (2019) showed that adaptation and dispersal conflict in the ability of species to survive environmental threats, pointing to the existence of two opposite strategies or tactics which species have to select in order to avoid disappearance. Here we prefer to turn the famous adage 'adapt or disperse' to 'move or change' because the latter has a wider acceptance. Movement of individuals for escaping bad conditions and reaching safe sites may occur at small scale without any necessary involvement in metacommunity dynamics, the background of dispersal (Mouquet and Loreau 2003). Accordingly, change has a wider acceptance than adaptation, because some basic textbooks still restrict the meaning of adaptation to the selection of favourable genotypes (Williams 2019), while individuals may change in the course of their life as a direct response to the environment (Colinet and Hoffmann 2012).

\section{Why and how to move?}

The active motility of collembolan species is highly variable, depending on whether animals are adapted to subterranean or aerial life and whether they possess organs making them able to walk or jump (Vanhee et al. 2017). By active movement they are able to select habitats within a circle of up to 200m, above which dispersal limitation is commonly observed at community level (Ponge and Salmon 2013). Exceptions are directional mass movements of surface-living Collembola, which have been observed in a little number of hypogastrurid and isotomid species (Hågvar 2000). Above the spatial threshold below which animals are able to wander by their own means in a heterogeneous environment, dispersal becomes a stochastic process mediated by long-distance carriers, e.g. birds, insects, wind, water (Hawes et al. 2008, Robin et al. 2019). 
Springtails have to move for a variety of reasons, e.g. foraging (Chauvat et al. 2014), mating (Hedlund et al. 1990), selection of favourable places for moulting and oviposition (Verhoef and Nagelkerke 1977, Benoit et al. 2009), avoidance of predation (Salmon 2004), toxicity (Michelozzi et al. 1997, Sjögren 1997), desiccation (Hayward et al. 2004), and more generally in search for more favourable conditions (Salmon et al. 2002). Active movement can occur from millimetre to decimetre scale, using chemical communication to detect food (Bengtsson et al. 1988, Salmon and Ponge 2001), sexual partners (Waldorf 1974, Zizzari et al. 2017) or environmental threats such as those potentially associated with dead conspecifics (Nilsson and Bengtsson 2004). Movement to places already occupied by conspecifics, which are conditioned by aggregation pheromones (Salmon et al. 2019), help to find safe sites for growth, reproduction and protection from natural enemies and environmental hazards (Wertheim et al. 2005), tendency for aggregation increasing with the age of animals (Barra and Christiansen 1975).

Small-scale movement may occur horizontally, for instance between adjacent patches of litter/vegetation (Auclerc et al. 2009), or vertically, between or within soil and litter horizons (Hassall et al. 1986, Sgardelis et al. 1993, Krab et al. 2010) or between vegetation and soil (Bowden et al. 1976). Vertical movement is favoured in soils having a network of earthworm galleries (Marinissen and Bok 1988, Salmon 2004). Small-scale movement can be directional, using olfactory cues (Auclerc et al. 2010) or non-directional, ceasing only when preferred habitat or food are randomly encountered (Nilsson and Bengtsson 2004). At larger scale, movement may occur among several favourable habitats distributed within a given landscape, colonization rate decreasing with distance (Hertzberg 1997, Ojala and Huhta 2001) and increasing with ancientness and quality of favoured habitats (Heiniger et al. 2014). The capacity of movement increases with size, larger species (Sjögren 1997) and adult stages (Johnson and Wellington 1983) moving to larger distances than smaller species and juvenile stages, respectively. The existence of a functional jumping apparatus and long legs associated with epigeic life (Salmon et al. 2014) still increases distances travelled (Chauvat et al. 2014). Movement occurs individually (Bengtsson et al. 2004), increasing at high population density (Bengtsson et al. 1994), or as mass movement at the surface of litter (Lyford 1975) or snow patches (Hågvar 1995). At last, large-scale passive travel by air (Hawes et al. 2007) and water (Schuppenhauer et al. 2019) has been recorded, and was shown or suspected to occur in the colonization of islands (Moore 2002), glacier moraines (Flø and Hågvar 2013), open cast mining areas (Dunger et al. 2002), mining refuse tips (Moore and Luxton 1986), tree canopies (Van der Wurff et al. 2003), or roofs (Joimel et al. 2018).

\section{Why and how to change?}


In Collembola, adaptive changes were mostly deduced from comparisons among existent populations, but recent developments in molecular biology allow or might allow to discern the mechanisms involved in evolutionary change. Most fruitful studies concerned the adaptation of Collembola to heavy metal toxicity. Duplication of the gene encoding metallothionein (MT, a sulphur-rich protein complexing metals) is known for a long time to confer tolerance to heavy metals in natural populations of Drosophila melanogaster (Maroni et al. 1987). This mechanism does not seem to occur in metaladapted populations of Collembola. In the species studied so far, Orchesella cincta, higher tolerance to cadmium was suggested to result from differential transcriptional regulation and selection of more efficient alleles at a single locus under metal stress (Janssens et al. 2009). However, a number of genes have been shown to have expanded as gene clusters, i.e. groups of genes coding for the same protein, some of them directly associated with metal stress tolerance, in the genome of $O$. cincta (FaddeevaVakhrusheva et al. 2016). Horizontal gene transfer (HGT), either from bacteria or fungal origin, has been also shown to have occurred repeatedly in the evolution of the genome of $O$. cincta, suggesting that HGT could have also played a role in its adaptation to metal stress (Faddeeva-Vakhrusheva et al. 2016). More research is needed, on a wider array of species, before reaching conclusions about the evolution of tolerance within Collembola. Epigenetic changes, such as those mediated by DNA methylation, have been shown to contribute to tolerance of environmental hazards in vertebrates and plants (Merritt and Bewick 2017), but have not been tested as yet in invertebrates.

It has been observed that sexual populations of the otherwise asexual (parthenogenetic) Mesaphorura macrochaeta commonly occur in stressed environments (Niklasson et al. 2000, Gillet and Ponge 2003). Sexual reproduction allows the selection of better-adapted combinations of alleles (Hickey and Golding 2018), but the mechanism of this reproductive shift is still unknown. Wolbachiainduced parthenogenesis is known to be the rule in M. macrochaeta (Czarnetzki and Tebbe 2003) but the sexual population from a metal-polluted site studied by Gillet and Ponge (2003) was shown to be cured of Wolbachia (Jacintha Ellers, personal communication), suggesting either (i) a detrimental effect of heavy metals on symbiotic bacteria or (ii) the selection of metal-tolerant bisexual strains within populations of M. macrochaeta. The adaptive (or maladaptive) value of Wolbachia infection remains to be demonstrated in Collembola, while studies on Drosophila showed that Wolbachia protect their host against pathogens (Martinez et al. 2014). Laboratory experiments by Chahartaghi et al. (2009) demonstrated that parthenogenetic collembolan species were faster colonizers than sexual species, supporting the classical hypothesis of parthenogenetic general purpose genotypes (Weider 1993) as having a wider geographical distribution (Lynch 1984). Alternative explanations have been given for the appearance of high phenotypic plasticity within species lineages, such as among others the accumulation of clonal diversity within asexual populations (Pound et al. 2004) or the inheritance 
130 of epigenetic modifications (e.g. DNA-methylation) under variable environmental conditions

131 (Massicotte and Angers 2012).

132 Non-adaptive changes also exist (Czekanski-Moir and Rundell 2019). They may result from 133 allopatric speciation, i.e. genetic drift following the establishment of a few founder individuals in an 134 environment identical from the area of origin but remote from it (Templeton 1980) or after the 135 appearance of a geographic barrier to gene flow, e.g. by fragmentation, within the original area 136 (Cracraft 1982). Geographic speciation has been shown to occur among cave Collembola (Katz et al. 137 2018) and both dispersal- and vicariance-driven processes have been demonstrated by phylogenetic 138 analysis in Antarctic springtails (McGaughran et al. 2010). However, non-geographic barriers (e.g. 139 reproductive isolation) also exist, reducing gene flow within populations, and thus favouring the 140 appearance of new species by sympatric or parapatric speciation (Bird et al. 2012). For instance 141 mutations may result in sexual isolation (Kaneshiro 1980) or habitat specialization (Kawecki 1997).

142 Sexual selection in Collembola can be traced from the choice exerted by females for spermatophores 143 produced by some males against others (Gols et al. 2004), with a preference for those of closely 144 related conspecifics (Hedlund et al. 1990). Chemical communication plays a prominent role in 145 collembolan mating, indirect sperm transfer and associated behaviour (Porco et al. 2004, Zizzari et al. 146 2017). The appearance of avoidance behaviour or even just the lack of chemical recognition among 147 conspecifics may also allow animals from the same original population to segregate in space or time 148 (Haim and Rozenfeld 1993, Guo et al. 2012). In Collembola, the checkerboard distribution of sibling 149 species with similar ecological requirements, like the widely distributed Holarctic sexual isotomids 150 Folsomia quadrioculata and Folsomia manolachei (Ponge and Salmon 2013), could be explained by 151 non-adaptive speciation mediated by behavioural divergence (Pillay and Rymer 2012).

\section{Move and change: vicariant or additive strategies?}

153 In stable environments (Levins 1962), periodic changes (e.g. seasons) or slow changes occurring along 154 decades (e.g. vegetation dynamics) allow animals to adapt their cycle (Takeda 1987). In the presence 155 of small-scale heterogeneity animals can move from one habitat to another (Loranger et al. 2001) 156 without the need to adapt themselves to novel conditions, and the same when recolonizing at short 157 distance after a disturbance (Alvarez et al. 2000, Auclerc et al. 2009). When the environment changes 158 suddenly and that above habitat requirements (e.g. following abrupt land use change), any given 159 population, to ensure its survival, has to strike a balance between long-distance dispersal to more 160 favourable habitats, or rapid adaptation (Pease et al. 1989). But what are the respective advantages and 161 disadvantages of dispersal and adaptation? The answer relies on interactions between species traits and 162 environmental features (Berg et al. 2010). Long-distance dispersal may occur by inter-patch movement within a landscape, following a 'stepping-stone' model (Kimura and Weiss 1964), with a 
strong discrepancy in successful establishment between species according to their tolerance to hostile matrices (Coulson et al. 2002). A high rate of mortality is expected in specialists, when forced to abandon their favoured habitat, while generalists are not endangered, at least in the short term (Heiniger et al. 2015). It has been shown on a wide array of plant and animal taxonomic groups that specialists may become generalists in a relatively short amount of time (Colles et al. 2009). Horizontal transfer of favourable genes (Faddeeva-Vakhrusheva et al. 2016), infection by Wolbachia (Timmermans et al. 2004), or epigenetic processes (Zizzari and Ellers 2014, Szabó et al. 2019) may contribute to such rapid adaptive changes in otherwise endangered species, but these events are rare and there is a high risk of species disappearance in the meantime, at least locally, stemming in ecological debt (Heiniger et al. 2014).

Let us take two examples showing that strongly divergent ecological groups of Collembola have adopted different combinations of 'move' and 'change' as efficient strategies face to environmental change.

Among epigeic species, Orchesella cincta is known to live in forest litter (Van Straalen et al. 1987), but this species is also able to live in moss, lichen and algal covers on tree trunks (Prinzing 2001, Shaw 2015) and in canopy-suspended soils (Shaw 2013). Genetic studies have shown that distances of several kilometres do not limit gene flow (Frati et al. 1992, Van der Wurff et al. 2003, 2005), genetic isolation occurring only at continental scale (Timmermans et al. 2005). Given that all populations exhibit a high allelic diversity (Timmermans et al. 2007, Janssens et al. 2007, 2008), it ensures that gene flow between remote populations is enough to ensure genetic mixing. This species most probably combines active movement within woody patches and transport by wind between patches, even remote ones when climbing on tree trunks and canopies (Prinzing and Wirtz 1997, Shaw 2015). The high allele variety (favoured by intense exchanges within sexual metapopulations) allows it to rapidly adapt to environmental hazards by allele recombination or selection of most efficient ones (Janssens et al. 2007, 2008, Bahrndorff et al. 2010). Thus the strategy adopted by $O$. cincta face to environmental hazards combines a high genetic diversity (based on genetic admixture and sexual reproduction) with active movement and long-distance passive dispersal among distant populations.

Among endogeic species, Folsomia candida is known to avoid light (Fox et al. 2007, Gallardo Ruiz et al. 2017), living in a subterranean space where movement is limited to the search for microbial food (Klironomos et al. 1999, Auclerc et al. 2010). Being parthenogenetic from Wolbachia infection (Vandekerckhove et al. 1999, Pike and Kingcombe 2009), there is no need to move for searching conspecifics, and reproduction occurs at a high rate in the absence of overcrowding (Green 1964), making the species able to colonize rapidly a novel environment (Dunger et al. 2002), starting from even a single female, like most laboratory strains were started (Fountain and Hopkin 2005). The 
existence of general-purpose genotypes has not been demonstrated in F. candida, but studies done as yet suggest that this species has adopted a strategy of high plasticity with extensive gene expression regulation (De Boer et al. 2011). F. candida is able to cope with nutrient scarcity (Hafer et al. 2011), drought and cold (Bayley et al. 2001), elevated carbon dioxide concentration (Jones et al. 1998) and pollution (Crommentuijn et al. 1995), with transgenerational transmission of acquired tolerance (Hafer et al. 2011). Mutations are probably not rare, given the high rate of successive reproductive waves from one individual (Fountain and Hopkin 2005). Despite the overall tolerance of the species, substantial variation exists among clones (Crommentuijn et al. 1995) and between individuals of the same clone (Crouau and Cazes 2003). Phylogenetic investigations showed that numerous strains exist, with two major clades derived from a unique ancestor (Tully et al. 2006), with small but clearly recognizable morphological differences among strains (Tully and Potapov 2015), each strain having its own reaction norms (Barateiro Diogo et al. 2007) and life-history traits (Mallard et al. 2015). A high rate of horizontal transfer, among the highest found in metazoan genomes, has been reported in the genome of $F$. candida (Faddeeva-Vakhrusheva et al. 2017).

Many other endogeic springtails share similar properties with $F$. candida, although they have not been studied in such detail. In particular, 'species' of the mostly parthenogenetic genus Mesaphorura exhibit strong morphological resemblances, justifying they were previously grouped in the unique species Tullbergia krausbaueri (Gisin 1960), later erected to genus level as Mesaphorura (Rusek 1971). The chaetotaxy, stable along several generations issued from a single specimen (Ponge, personal observations), allowed the recognition of a huge and still increasing number of 'species' which may differ only by the presence or absence of a single pair of minute hairs on the integument. It has been shown that at least some of these 'species' differ in their ecological preferences (Dunger 1991, Ponge 1993) and their molecular patterns (Zimdars and Dunger 2000), despite the fact that several Mesaphorura 'species' commonly live together in the same soil volume (Ponge, personal observations). This suggests that they do not differ in their taxonomic status from the various strains of $F$. candida. Similar to $F$. candida, Mesaphorura species have a high reproductive rate, hence their use as laboratory test animals (Boitaud et al. 2006, Sechi et al. 2014), but unfortunately their tolerance to stress factors has not been studied yet, making further comparisons impossible. We only know that sexual populations of the most common species, M. macrochaeta, are present in stressed environments. This could mean that sexual reproduction occurs as an alternative to parthenogenesis only in extreme environments. The strategy adopted by $F$. candida (and most probably other Wolbachia-infected parthenogenetic springtails) is thus based on a high genetic diversity, with the rapid occurrence of mutations (linked to high reproductive rates), combined with a high phenotypic plasticity, general-purpose genotypes remaining to be discovered, but being highly probable. Largescale movement does not take place in this strategy. 
These two cases are extreme cases, exemplifying opposite strategies adopted by belowground versus aboveground species (Van Dooremalen et al. 2013). It is highly probable that many species, in particular species living in litter, the so-called 'hemiedaphic' ecological group (Nickerl et al. 2013), combine movement and change (whether genetic or phenotypic, whether based on mutation or recombination) to ensure their survival (Fig. 1). The two above cited model species, $F$. candida and $O$. cincta, displaying opposite strategies of move and change, have been positioned at lower and upper sides of Siepel's scaling of life cycles in microarthropods (Siepel 1994), respectively. However, most collembolan species, and in particular those living in litter, are midway along this scale of increasing juvenile stage duration and decreasing clutch size which follows the classical r-K selection gradient (Pianka 1970). Awaiting further research on collembolan life-history traits it can be hypothesized that trade-offs exist between the cost of move (Bonte et al. 2012) and the cost of change (Kawecki 1994).

We may now ask whether the hypothesis of two alternative strategies, here called 'move' and 'change' can be falsified. In other terms, are 'move' species able to adapt to changing conditions without resorting to movement. And, conversely, are 'change' species able to move to better habitats? Examples can be found in the above cited species. The overexpression of genes coding for metallothionein in populations of Orchesella cincta from metal-contaminated areas (Roelofs et al. 2009), most probably of epigenetic origin (Janssens et al. 2009, Boyko and Kovalchuk 2011), indicate the capacity of a 'move' species to rapidly adapt to environmental stress. Dunger et al. (2002) showed that Mesaphorura spp. and Folsomia candida were early colonizers of open-cast mine areas, together with wind-transported epigeic springtails. This suggests that 'change' species can travel long distances with other means of dispersal than wind. Bird geophagy (Downs et al. 2019) and the well-known adhesion of earth to bird legs and beaks (Darwin 1859) can be suggested as potential mechanisms for this still poorly studied phenomenon of long-distance travel of edaphic species. Awaiting more research on this topic these two examples show that 'move' and 'change' strategies can be additive rather than mutually exclusive.

\section{'Move' or 'change' as a response to global change: which perspectives?}

Collembolan species with functional traits giving them a higher dispersal capacity (e.g. large body size, long furcula and legs, fully developed visual organs), here called 'move' species, are resistant to small-scale temporary disturbances, being able to recolonize easily after e.g. fire (Malmström 2012) or in the course of cultural cycles (Alvarez et al. 2000). However, in the case of cyclic, predictable disturbances occurring in natural and agricultural habitats, other strategies, such as changes in vertical distribution (Hassall et al. 1986) or survival as dormant eggs (Leinaas and Bleken 1983, Tamm 1986), are also observed. But what happens and will happen in the case of long-standing changes, such as present-day climate warming? In a 16-yr warming field experiment where subarctic Collembola were 
able to migrate in and out of open top chambers, species having traits associated with the 'move' strategy did not follow the overall decrease in abundance and species richness associated with higher temperature and lower moisture (Makkonen et al. 2011). However, straightforward advantages of 'move' species, observed in subarctic collembolan communities in the frame of climate warming, were not supported by other studies on communities from milder climates. For instance Yin et al. (2019) showed that climate change had a negligible impact on collembolan communities compared to land use change, although there was a strong interaction between land use and sensitivity to climate. By sampling Collembola over several years widely differing in climate conditions, Pollierer and Scheu (2017) showed that 'change' (parthenogenetic) species were sensitive to climate variation while 'move' (sexual) species were not. While more studies based on functional traits are awaited, 'move' species can be thought at first sight better able to cope with rapidly changing environments than 'change' species, given their ability to move to distant, favourable habitats (Ponge et al. 2006). However we may ask whether there are limits to this adaptive behaviour in the frame of present-day climate warming. In other terms, can dispersal limitation affect 'move' species if warming occurs at a too high rate? Given that a $100 \mathrm{~m}$ altitudinal gradient translates in a $100 \mathrm{~km}$ latitudinal gradient in terms of temperature variation (Jump et al. 2009), then a thousand times more time will be required along latitudinal versus altitudinal gradients to track shifts in suitable climate (Schloss et al. 2012). This rough calculation points to extinction risks for 'move' species if they rely only on this strategy for their survival, to the exception of mountains which may play the role of less distant refuges if locally present (Wright et al. 2009).

It can be hypothesized that in face of present-day climate change, inherently associated with high land use turnover (Ojima et al. 1994), 'change' species with low dispersal rate will be threatened compared to "move' species, at least locally and temporarily if they have a wide distribution area (Ponge and Salmon 2013) or at worldwide scale and definitively if they are endemic and specialized on rarefying habitats (Garrick et al. 2004). However, among 'change' species, those having a high phenotypic plasticity are prone to escape this genetic bottleneck. Species such as Mesaphorura macrochaeta have even been shown to thrive in disturbed environments where other species fail to survive (Gillet and Ponge 2003).

As a conclusion, we showed that collembolan species have at their disposal two opposite strategies to face environmental hazards, among them the ongoing sixth mass extinction. Whether trade-offs exist between these strategies is still a matter of conjecture, given the scarcity of studies on the evolution of functional traits associated with collembolan tolerance (Van Dooremalen et al. 2013, Prinzing et al. 2014, Tully and Potapov 2015). We hope that the present opinion paper will stimulate future studies on the evolutionary ecology of Collembola, on the model of those already engaged by Berg et al. (2010) and Thompson and Fronhofer (2019). 


\section{References}

Alvarez T, Frampton GK, Goulson D (2000) The role of hedgerows in the recolonisation of arable fields by epigeal Collembola. Pedobiologia 44:516-526. https://doi.org/10.1078/S0031$\underline{4056(04) 70068-2}$

Amemiya CT, Alföldi J, Lee AP, Fan SH, Philippe H, MacCallum I, Braasch I, Manousaki T, Schneider I, Rohner N et al. (2013) The African coelacanth genome provides insights into tetrapod evolution. Nature 496:311-316. https://doi.org/10.1038/nature12027

Auclerc A, Libourel PA, Salmon S, Bels V, Ponge JF (2010) Assessment of movement patterns in Folsomia candida (Hexapoda: Collembola) in the presence of food. Soil Biol Biochem 42:657-659. https://doi.org/10.1016/j.soilbio.2009.12.012

Auclerc A, Ponge JF, Barot S, Dubs F (2009) Experimental assessment of habitat preference and dispersal ability of soil springtails. Soil Biol Biochem 41:1596-1604. https://doi.org/10.1016/j.soilbio.2009.04.017

Bahrndorff S, Mariën J, Loeschcke V, Ellers J (2010) Genetic variation in heat resistance and HSP70 expression in inbred isofemale lines of the springtail Orchesella cincta. Clim Res 43:41-47. https://doi.org/10.3354/cr00896

Barateiro Diogo J, Natal-da-Luz T, Sousa JP, Vogt C, Nowak C (2007) Tolerance of genetically characterized Folsomia candida strains to phenmedipham exposure. J Soils Sedim 7:388-392. https://doi.org/10.1065/jss2007.09.252

Barnosky AD, Matzke N, Tomiya S, Wogan GOU, Swartz B, Quental TB, Marshall C, McGuire JL, Lindsey EL, Maguire KC, Mersey B, Ferrer EA (2011) Has the Earth's sixth mass extinction already arrived? Nature 471:51-57. https://doi.org/10.1038/nature09678

Barra JA, Christiansen K (1975) Experimental study of aggregation during development of Pseudosinella impediens (Collembola, Entomobryidae). Pedobiologia 15:343-347

Bayley M, Petersen SO, Knigge T, Köhler HR, Holmstrup M (2001) Drought acclimation confers cold tolerance in the soil collembolan Folsomia candida. J Insect Physiol 47:1197-1204. https://doi.org/10.1016/S0022-1910(01)00104-4

Bengtsson G, Erlandsson A, Rundgren S (1988) Fungal odour attracts soil Collembola. Soil Biol Biochem 20:25-30. https://doi.org/10.1016/0038-0717(88)90122-8 
Bengtsson G, Hedlund K, Rundgren S (1994) Food- and density-dependent dispersal: evidence from a soil collembolan. J Anim Ecol 63:513-520. https://doi.org/10.2307/5218

Bengtsson G, Nilsson E, Rydén T, Wiktorsson M (2004) Irregular walks and loops combines in smallscale movement of a soil insect: implications for dispersal biology. J Theor Biol 231:299-306. https://doi.org/10.1016/j.jtbi.2004.06.025

Benoit, JB, Elnitsky MA, Schulte GG, Lee RE, Denlinger DL (2009) Antarctic collembolans use chemical signals to promote aggregation and egg laying. J Ins Behav 22:121-133. https://doi.org/10.1007/s10905-008-9159-7

Berg MP, Kiers ET, Driessen G, Van der Heijden M, Kooi BW, Kuenen F, Liefting M, Verhoef HA, Ellers J (2010) Adapt or disperse: understanding species persistence in a changing world. Global Change Biol 16:587-598. https://doi.org/10.1111/j.1365-2486.2009.02014.x

Bird CE, Fernandez-Silva I, Skillings DJ, Toonen RJ (2012) Sympatric speciation in the post "Modern Synthesis" era of evolutionary biology. Evol Biol 39:158-180. https://doi.org/10.1007/s11692-012-9183-6

Boitaud L, Salmon S, Bourlette C, Ponge JF (2006) Avoidance of low doses of naphthalene by Collembola. Environ Pollut 139:451-454. https://doi.org/10.1016/j.envpol.2005.06.013

Bonte D, Van Dyck H, Bullock JM, Coulon A, Delgado M, Gibbs M, Lehouck V, Matthysen E, Mustin K, Saastamoinen M, Schtickzelle N, Stevens VM, Vandewoestijne S, Baguette M, Barton K, Benton TG, Chaput-Bardy A, Clobert J, Dytham C, Hovestadt T, Meier CM, Palmer SCF, Turlure C, Travis JMJ (2012) Costs of dispersal. Biol Rev 87:290-312. https://doi.org/10.1111/j.1469-185X.2011.00201.X

Bowden J, Haines IH, Mercer D (1976) Climbing Collembola. Pedobiologia 16:298-312

Boyko A, Kovalchuk I (2011) Genome instability and epigenetic modification: heritable responses to environmental stress? Curr Opinion Plant Biol 14:260-266. http://dx.doi.org/10.1016/j.pbi.2011.03.003

Chahartaghi M, Maraun M, Scheu S, Domes K (2009) Resource depletion and colonization: a comparison between parthenogenetic and sexual Collembola species. Pedobiologia 52:181-189. https://doi.org/10.1016/j.pedobi.2008.08.003

Chauvat M, Perez G, Ponge JF (2014) Foraging patterns of soil springtails are impacted by food resources. Appl Soil Ecol 82:72-77. https://doi.org/10.1016/j.apsoil.2014.05.012 
Christiansen K, Pike E (2002) Cretaceous Collembola (Arthropoda, Hexapoda) from the Upper Cretaceous of Canada. Cretaceous Res 23:165-188. https://doi.org/10.1006/cres.2002.0313

Colinet H, Hoffmann AA (2012) Comparing phenotypic effects and molecular correlates of developmental, gradual and rapid cold acclimation responses in Drosophila melanogaster. Funct Ecol 26:84-93. https://doi.org/10.1111/j.1365-2435.2011.01898.x

Colles A, Liow LH, Prinzing A (2009) Are specialists at risk under environmental change? Neoecological, paleoecological and phylogenetic approaches. Ecol Lett 12:849-863. https://doi.org/10.1111/j.1461-0248.2009.01336.x

Coulson SJ, Hodkinson ID, Webb NR, Harrison JA (2002) Survival of terrestrial soil-dwelling arthropods on and in seawater: implications for trans-oceanic dispersal. Funct Ecol 16:353-356. https://doi.org/10.1046/j.1365-2435.2002.00636.x

Cracraft J (1982) A nonequilibrium theory for the rate-control of speciation and extinction and the origin of macroevolutionary patterns. Syst Zool 31:348-365. https://doi.org/10.1093/sysbio/31.4.348

Crommentuijn T, Stäb JA, Doornekamp A, Estoppey O, Van Gestel CAM (1995) Comparative ecotoxicity of cadmium, chlorpyrifos and triphenyltin hydroxide for four clones of the parthenogenetic collembolan Folsomia candida in an artificial soil. Funct Ecol 9:734-742. https://doi.org/10.2307/2390246

Crouau Y, Cazes L (2003) What causes variability in the Folsomia candida reproduction test? Appl Soil Ecol 22:175-180. https://doi.org/10.1016/S0929-1393(02)00128-2

Czarnetzki AB, Tebbe CC (2003) Detection and phylogenetic analysis of Wolbachia in Collembola. Environ Microbiol 6:35-44. https://doi.org/10.1046/j.1462-2920.2003.00537.x

Czekanski-Moir JE, Rundell RJ (2019) The ecology of nonecological speciation and nonadaptive radiations. Trends Ecol Evol 34:400-415. https://doi.org/10.1016/j.tree.2019.01.012

Darwin C (1859) On the Origin of Species by Means of Natural Selection, or the Preservation of Favoured Races in the Struggle for Life. John Murray, London.

De Boer TE, Birlutiu A, Bochdanovits Z, Timmermans MJTN, Dijkstra TMH, Van Straalen NM, Ylstra B, Roelofs D (2011) Transcriptional plasticity of a soil arthropod across different ecological conditions. Mol Ecol 20:1144-1154. https://doi.org/10.1111/j.1365294x.2010.04985.X 
Dirzo R, Young HS, Galetti M, Ceballos G, Isaac NJB, Collen B (2014) Defaunation in the Anthropocene. Science 345:401-406. https://doi.org/10.1126/science.1251817

Downs CT, Bredin IP, Wragg PD (2019) More than eating dirt: a review of avian geophagy. Afr Zool 54:1-19. https://doi-org.inee.bib.cnrs.fr/10.1080/15627020.2019.1570335

Dunger W (1991) Ökologische Prüfung von Morphospecies der "Tullbergia krausbaueri-Gruppe" (Insecta: Collembola). Mittl Zool Mus Berlin 67:131-140. https://doi.org/10.1002/mmnz.19910670118

Dunger W, Schulz HJ, Zimdars B (2002) Colonization behaviour of Collembola under different conditions of dispersal. Pedobiologia 46:316-327. https://doi.org/10.1016/S0031$\underline{4056(04) 70148-1}$

Faddeeva-Vakhrusheva A, Derks MF, Anvar SY, Agamennone V, Suring W, Smit S, Van Straalen NM, Roelofs D (2016) Gene family evolution reflects adaptation to soil environmental stressors in the genome of the collembolan Orchesella cincta. Sci Rep 7:2675. https://doi.org/10.1093/gbe/evw134

Faddeeva-Vakhrusheva A, Kraaijeveld K, Derks MFL, Anvar SY, Agamennone V, Suring W, Kampfraath AA, Ellers J, Le Ngoc G, Van Gestel CAM, Mariën J, Smit S, Van Straalen NM, Roelofs D (2017) Coping with living in the soil: the genome of the parthenogenetic springtail Folsomia candida. BMC Genomics 18:493. https://doi.org/10.1186/s12864-017-3852-x

Flø D, Hågvar S (2013) Aerial dispersal of invertebrates and mosses close to a receding alpine glacier in southern Norway. Arctic Antarctic Alpine Res 45:481-490. https://doi.org/10.1657/1938$\underline{4246-45.4 .481}$

Fountain MT, Hopkin SP (2005) Folsomia candida (Collembola): a "standard" soil arthropod. Ann Rev Entomol 50:201-222. https://doi.org/10.1146/annurev.ento.50.071803.130331

Fox GL, Coyle-Thompson CA, Bellinger PF, Cohen RW (2007) Phototactic responses to ultraviolet and white light in various species of Collembola, including the eyeless species, Folsomia candida. J Insect Sci 7:22. https://doi-org.eres.qnl.qa/10.1673/031.007.2201

Frati F, Fanciulli P, Posthuma L (1992) Allozyme variation in reference and metal-exposed natural populations of Orchesella cincta (Insecta: Collembola). Biochem Syst Ecol 20:297-310. https://doi.org/10.1016/0305-1978(92)90041-B 
Gallardo Ruiz M, Le Galliard JF, Tully T (2017) Genetic variation in light vision and light-dependent movement behaviour in the eyeless Collembola Folsomia candida. Pedobiologia 61:33-41. https://doi.org/10.1016/j.pedobi.2016.12.001

Garrick RC, Sands CJ, Rowell DM, Tait NN, Greenslade P, Sunnucks P (2004) Phylogeography recapitulates topography: very fine-scale local endemism of a saproxylic 'giant' springtail at Tallaganda in the Great Dividing Range of south-east Australia. Mol Ecol 13:3329-3344. https://doi.org/10.1111/j.1365-294X.2004.02340.x

Gillet S, Ponge JF (2003) Changes in species assemblages and diets of Collembola along a gradient of metal pollution. Appl Soil Ecol 22:127-138. https://doi.org/10.1016/S0929-1393(02)00134-8

Gisin H (1960) Collembolenfauna Europas. Muséum d'Histoire Naturelle, Geneva

Gols R Ernsting G, Van Straalen NM (2004) Paternity analysis in a hexapod (Orchesella cincta; Collembola) with indirect sperm transfer. J Insect Behav 17:317-328. https://doi.org/10.1023/B:JOIR.0000031533.32859.ba

Gould SJ, Eldredge N (1993) Punctuated equilibrium comes of age. Nature 366:223-227. https://doi.org/10.1038/366223a0

Green CD (1964) The effect of crowding upon the fecundity of Folsomia candida (William) var. distincta (Bagnall) (Collembola). Ent Exp Appl 7:62-70. https://doi.org/10.1111/j.15707458.1964.tb00726.x

Greenslade P, Whalley PES (1986) The systematic position of Rhyniella praecursor Hirst et Maulik (Collembola): the earliest known hexapod. In: Dallai J (ed) Second International Seminar on Apterygota, Siena, Italy, September 4-6, 1986. University of Siena, Siena, pp 319-323

Guo H, Huang LQ, Pelosi P, Wang CZ (2012) Three pheromone-binding proteins help segregation between two Helicoverpa species utilizing the same pheromone components. Insect Biochem Mol Biol 42:708-716. http://dx.doi.org/10.1016/j.ibmb.2012.06.004

Hädicke CW, Haug C, Haug JT (2013) Adding to the few: a tomocerid collembolan from Baltic amber. Palaeodiv 6:149-156

Hafer N, Ebil S, Uller T, Pik N (2011) Transgenerational effects of food availability on age at maturity and reproductive output in an asexual collembolan species. Biol Lett 7:755-758. https://doi.org/10.1098/rsbl.2011.0139 
Hågvar S (1995) Long distance, directional migration on snow in a forest collembolan, Hypogastrura socialis (Uzel). Acta Zool Fenn 196:200-205

Hågvar S (2000) Navigation and behaviour of four Collembola species migrating on the snow surface. Pedobiologia 3-4:221-233. https://doi.org/10.1078/S0031-4056(04)70042-6

Haim A, Rozenfeld FM (1993) Temporal segregation in coexisting Acomys species: the role of odour. Physiol Behav 54:1159-1161. https://doi.org/10.1016/0031-9384(93)90341-c

Hassall M, Visser S, Parkinson D (1986) Vertical migration of Onychiurus subtenuis (Collembola) in relation to rainfall and microbial activity. Pedobiologia 29:175-182

Hawes TC, Worland MR, Bale JS, Convey P (2008) Rafting in Antarctic Collembola. J Zool 274:44-50. https://doi.org/10.1111/j.1469-7998.2007.00355.x

Hawes TC, Worland MR, Convey P, Bale JS (2007) Aerial dispersal of springtails on the Antarctic Peninsula: implications for local distribution and demography. Antarctic Sci 19:3-10. https://doi.org/10.1017/S0954102007000028

Hayward SAL, Worland MR, Convey P, Bale JS (2004) Habitat moisture availability and the local distribution of the Antarctic Collembola Cryptopygus antarcticus and Friesea grisea. Soil Biol Biochem 36:927-934. https://doi.org/10.1016/j.soilbio.2004.02.007

Hedlund K, Ek H, Gunnarsson T, Svegborn C (1990) Mate choice and male competition in Orchesella cincta (Collembola). Experientia 46:524-526. https://doi.org/10.1007/BF01954254

Heiniger C, Barot S, Ponge JF, Salmon S, Botton-Divet L, Carmignac D, Dubs F (2014) Effect of habitat spatiotemporal structure on collembolan diversity. Pedobiologia 57:103-117. https://doi.org/10.1016/j.pedobi.2014.01.006

Heiniger C, Barot S, Ponge JF, Salmon S, Meriguet J, Carmignac D, Suillerot M, Dubs F (2015) Collembolan preferences for soil and microclimate in forest and pasture communities. Soil Biol Biochem 86:181-192. https://doi.org/10.1016/j.soilbio.2015.04.003

Hertzberg K (1997) Migration of Collembola in a patchy environment. Pedobiologia 41:494-505

Hickey DA, Golding GB (2018) The advantage of recombination when selection is acting at many genetic loci. J Theor Biol 442:123-128. https://doi.org/10.1016/j.jtbi.2018.01.018

Hopkin SP (1997) Biology of the springtails. Oxford University Press, Oxford 
Janssens TKS, Lopéz R del R, Mariën J, Timmermans MJ, Montagne-Wajer K, Van Straalen NM, Roelofs D (2008) Comparative population analysis of metallothionein promoter alleles suggests stress-induced microevolution in the field. Environ Sci Technol 42:3873-3878. https://doi.org/10.1021/es702618s

Janssens TKS, Mariën J, Cenijn P, Legler J, Van Straalen NM, Roelofs D (2007) Recombinational micro-evolution of functionally different metallothionein promoter alleles from Orchesella cincta. BMC Evol Biol 7:88. https://doi.org/10.1186/1471-2148-7-88

Janssens TKS, Roelofs D, Van Straalen NM (2009) Molecular mechanisms of heavy metal tolerance and evolution in invertebrates. Insect Sci 16:3-18. https://doi.org/10.1111/j.17447917.2009.00249.x

Johnson DL, Wellington WG (1983) Dispersal of the collembolan, Folsomia candida Willem, as a function of age. Can J Zool 61:2534-2538. https://doi.org/10.1139/z83-335

Joimel S, Grard B, Auclerc A, Hedde M, Le Doare N, Salmon S, Chenu C (2018) Are Collembola "flying" onto green roofs? Ecol Engineer 111:117-124. https://doi.org/10.1016/j.ecoleng.2017.12.002

Jones TH, Thompson LJ, Lawton JH, Bezemer TM, Bardgett RD, Blackburn TM, Bruce KD, Cannon PF, Hall GS, Hartley SE, Howson G, Jones CG, Kampichler C, Kandeler E, Ritchie DA (1998) Impacts of rising atmospheric carbon dioxide on model terrestrial ecosystems. Science 280:441-443. https://doi.org/10.1126/science.280.5362.441

Jump AS, Mátyás C, Peñuelas J (2009) The altitude-for-latitude disparity in the range retractions of woody species. Trends Ecol Evol 24:694-701. https://doi.org/10.1016/j.tree.2009.06.007

Kaneshiro KY (1980) Sexual isolation, speciation and the direction of evolution. Evolution 34:437-444. https://doi.org/10.2307/2408213

Katz AD, Taylor SJ, Davis MA (2018) At the confluence of vicariance and dispersal: phylogeography of cavernicolous springtails (Collembola: Arrhopalitidae, Tomoceridae) codistributed across a geologically complex karst landscape in Illinois and Missouri. Ecol Evol 8:10306-10325. https://doi.org/10.1002/ece3.4507

Kawecki TJ (1994) Accumulation of deleterious mutations and the evolutionary cost of being a generalist. Am Nat 144:833-838. https://doi.org/10.1086/285709

Kawecki TJ (1997) Sympatric speciation by habitat specialization driven by deleterious mutations. Evolution 51:1751-1763. https://doi.org/10.1111/j.1558-5646.1997.tb05099.x 
Kimura M, Weiss GH (1964) The stepping stone model of population structure and the decrease of genetic Correlation with distance. Genetics 49:561-576

Klironomos JN, Bednarczuk EM, Neville J (1999) Reproductive significance of feeding on saprobic and arbuscular mycorrhizal fungi by the collembolan, Folsomia candida. Funct Ecol 13:756-761. https://doi.org/10.1046/j.1365-2435.1999.00379.x

Krab EJ, Oorsprong H, Berg MP, Cornelissen JHC (2010) Turning northern peatlands upside down: disentangling microclimate and substrate quality effects on vertical distribution of Collembola. Funct Ecol 24:1362-1369. https://doi.org/10.1111/j.1365-2435.2010.01754.x

Leinaas HP, Bleken E (1983) Egg diapause and demographic strategy in Lepidocyrtus lignorum Fabricius (Collembola; Entomobryidae). Oecologia 58:194-199. https://doi.org/10.1007/BF00399216

Levins R (1962) Theory of fitness in a heterogeneous environment. I. The fitness set and adaptive function. Am Nat 96:361-373. https://doi.org/10.1086/282245

Loranger G, Bandyopadhyaya I, Razaka B, Ponge JF (2001) Does soil acidity explain altitudinal sequences in collembolan communities? Soil Biol Biochem 33:381-393. https://doi.org/10.1016/S0038-0717(00)00153-X

Lyford WH (1975) Overland migration of Collembola (Hypogastrura nivicola Fitch) colonies. Am Midl Nat 94:205-209. https://doi.org/10.2307/2424550

Lynch M (1984) Destabilizing hybridization, general-purpose genotypes and geographic parthenogenesis. Quart Rev Biol 59:257-290. https://doi.org/10.1086/413902

MakkonenM, Berg MP, Van Hal JR, Callaghan TV, Press MC, Aerts R (2011) Traits explain the responses of a sub-arctic Collembola community to climate manipulation. Soil Biol Biochem 43:377-384. https://doi.org/10.1016/j.soilbio.2010.11.004

Mallard F, Farina M, Tully T (2015) Within-species variation in long-term trajectories of growth, fecundity and mortality in the Collembola Folsomia candida. J Evol Biol 28:2275-2284. https://doi.org/10.1111/jeb.12752

Malmström A (2012) Life-history traits predict recovery patterns in Collembola species after fire: a 10 year study. Appl Soil Ecol 56:35-42. https://doi.org/10.1016/j.apsoil.2012.02.007

Marinissen JCY, Bok J (1988) Earthworm-amended soil structure: its influence on Collembola populations in grassland. Pedobiologia 32:243-252 
Maroni G, Wise J, Young JE, Otto E (1987) Metallothionein gene duplications and metal tolerance in natural populations of Drosophila melanogaster. Genetics 117:739-744

Martinez J, Longdon B, Bauer S, Chan YS, Miller WJ, Bourtzis K, Teixeira L, Jiggins FM (2014) Symbionts commonly provide broad spectrum resistance to viruses in insects: a comparative analysis of Wolbachia strains. PLoS Pathog 10:e1004369. https://doi.org/10.1371/journal.ppat.1004369

Massicotte R, Angers B (2012) General-purpose genotype of how epigenetics extend the flexibility of a genotype. Gen Res Int 2012:317175. http://dx.doi.org/10.1155/2012/317175

McGaughran A, Stevens MI, Holland BR (2010) Biogeography of circum-Antarctic springtails. Mol Phylogenet Evol 57:48-58. https://doi.org/10.1016/j.ympev.2010.06.003

McLoughlin S, Vajda V (2005) Ancient wollemi pines resurgent. Am Sci 93:540-547. https://doi.org/10.1511/2005.56.981

Merritt TJS, Bewick AJ (2017) Genetic diversity in insect metal tolerance. Front Genet 8:172. https://doi.org/10.3389/fgene.2017.00172

Michelozzi M, Raschi A, Tognetti R, Tosi L (1997) Eco-ethological analysis of the interaction between isoprene and the behaviour of Collembola. Pedobiologia 41:210-214

Moore FR, Luxton M (1986) The collembolan fauna of two coal shale tips in north-west England. Pedobiologia 29:359-366

Moore PD (2002) Springboards for springtails. Nature 418:381. https://doi.org/10.1038/418381a

Mouquet N, Loreau M (2003) Community patterns in source-sink metacommunities. Am Nat 162:544-567. https://doi.org/10.1086/378857

Nickerl J, Helbig R, Schulz HJ, Werner C, Neinhuis C (2013) Diversity and potential correlations to the function of Collembola cuticle structures. Zoomorphol 132:183-195. https://doi.org/10.1007/s00435-012-0181-0

Niklasson M, Petersen H, Parker ED Jr (2000) Environmental stress and reproductive mode in Mesaphorura macrochaeta (Tullbergiinae, Collembola). Pedobiologia 44:476-488. https://doi.org/10.1078/S0031-4056(04)70065-7

Nilsson E, Bengtsson G (2004) Death odour changes movement pattern of a Collembola. Oikos 104:509-517. https://doi.org/10.1111/j.0030-1299.2004.12921.x 
Ojala R, Huhta V (2001) Dispersal of microarthropods in forest soil. Pedobiologia 45:443-450. https://doi.org/10.1078/0031-4056-00098

Ojima DS, Galvin KA, Turner, BL II (1994) The global impact of land-use change. BioScience 44:300-304. https://doi.org/10.2307/1312379

Pease CM, Lande R, Bull JJ (1989) A model of population growth, dispersal and evolution in a changing environment. Ecology 70:1657-1664. https://doi.org/10.2307/1938100

Pianka ER (1970) On r- and K-selection. Am Nat 104:592-597. https://doi.org/10.1086/282697

Pike N, Kingcombe R (2009) Antibiotic treatment leads to the elimination of Wolbachia endosymbionts and sterility in the diplodiploid collembolan Folsomia candida. BMC Biol 7:54. https://doi.org/10.1186/1741-7007-7-54

Pillay N, Rymer TL (2012) Behavioural divergence, interfertility and speciation: a review. Behav Proc 91:223-235. https://doi.org/10.1016/j.beproc.2012.08.0

Pollierer MM, Scheu S (2017) Driving factors and temporal fluctuation of Collembola communities and reproductive mode across forest types and regions. Ecol Evol 7:4390-4403. https://doi.org/10.1002/ece3.3035

Ponge JF (1993) Biocenoses of Collembola in atlantic temperate grass-woodland ecosystems. Pedobiologia 37:223-244

Ponge JF, Dubs F, Gillet S, Sousa JP, Lavelle P (2006) Decreased biodiversity in soil springtail communities: the importance of dispersal and landuse history in heterogeneous landscapes. Soil Biol Biochem 38:1158-1161. https://doi.org/10.1016/j.soilbio.2005.09.004

Ponge JF, Salmon S (2013) Spatial and taxonomic correlates of species and species trait assemblages in soil invertebrate communities. Pedobiologia 56:129-136. https://doi.org/10.1016/j.pedobi.2013.02.001

Porco D, Deharveng L, Gers C (2004) Sexual discrimination with cuticular lipids in Schoettella ununguiculata (Tullberg, 1869) (Collembola: Hypogastruridae). Pedobiologia 48:581-583. https://doi.org/10.1016/j.pedobi.2004.05.010

Pound GE, Cox SJ, Doncaster CP (2004) The accumulation of deleterious mutations within the frozen niche variation hypothesis. J Evol Biol 17:651-662. https://doi.org/10.1111/j.14209101.2003.00690.x 
Prinzing A, D'Haese CA, Pavoine S, Ponge JF (2014) Species living in harsh environments have low clade rank and are localized on former Laurasian continents: a case study of Willemia (Collembola). J Biogeogr 41:353-365. https://doi.org/10.1111/jbi.12188

Prinzing A, Wirtz HP (1997) The epiphytic lichen, Evernia prunastri L., as a habitat for arthropods: shelter from desiccation, food limitation and indirect mutualism. In: Canopy Arthropods, eds. Stork NE, Adis J, Didham RK. Chapman and Hall, London, pp. 477-494.

Prinzing AJ (2001) Use of shifting microclimatic mosaics by arthropods on exposed tree trunks. Ann Entom Soc Am 94:210-218. https://doi.org/10.1603/00138746(2001)094[0210:UOSMMB]2.0.CO;2

Richards WR (1968) Generic classification, evolution, and biogeography of the Sminthuridae of the world (Collembola). Mem Entomol Soc Can 200:3-54. https://doi.org/10.4039/entm10053fv

Robin N, D'Haese C, Barden P (2019) Fossil amber reveals springtails' longstanding dispersal by social insects. BMC Evol Biol 19:213. https://doi.org/10.1186/s12862-019-1529-6

Roelofs D, Janssens TK, Timmermans MJ, Nota B, Mariën J, Bochdanovits Z, Ylstra B, Van Straalen NM (2009) Adaptive differences in gene expression associated with heavy metal tolerance in the soil arthropod Orchesella cincta. Mol Ecol 18:3227-3239. https://doi.org/10.1111/j.1365294X.2009.04261.x

Rusek J (1971) Zur Taxonomie der Tullbergia (Mesaphorura) krausbaueri (Börner) und ihrer Verwandten (Collembola). Acta Ent Bohemoslov 68:188-206

Salmon S (2004) The impact of earthworms on the abundance of Collembola: improvement of food resources or of habitat? Biol Fertil Soils 40:323-333. https://doi.org/10.1007/s00374-004$\underline{0782-\mathrm{y}}$

Salmon S, Ponge JF (2001) Earthworm excreta attract soil springtails: laboratory experiments on Heteromurus nitidus (Collembola: Entomobryidae). Soil Biol Biochem 33:1959-1969. https://doi.org/10.1016/S0038-0717(01)00129-8

Salmon S, Ponge JF (2012) Species traits and habitats in springtail communities: a regional scale study. Pedobiologia 55:295-301. https://doi.org/10.1016/j.pedobi.2012.05.003

Salmon S, Ponge JF, Gachet S, Deharveng L, Lefebvre N, Delabrosse F (2014) Linking species, traits and habitat characteristics of Collembola at European scale. Soil Biol Biochem 75:73-85. https://doi.org/10.1016/j.soilbio.2014.04.002 
626

627

628

629

630

631

632

633

634

635

636

637

638

639

640

641

642

643

644

645

646

647

648

649

650

651

652

653

654

Salmon S, Ponge JF, Van Straalen NM (2002) Ionic identity of pore water influences $\mathrm{pH}$ preference in Collembola. Soil Biol Biochem 34:1663-1667. https://doi.org/10.1016/S0038$\underline{0717(02) 00150-5}$

Salmon S, Rebuffat S, Prado S, Sablier M, D’Haese C, Sun JS, Ponge JF (2019) Chemical communication in springtails: a review of facts and perspectives. Biol Fertil Soils 55:425-438. https://doi.org/10.1007/s00374-019-01365-8

Sánchez-García A, Engel MS (2017) Long-term stasis in a diverse fauna of Early Cretaceous springtails (Collembola: Symphypleona). J Syst Palaeontol 15:513-537. https://doi.org/10.1080/14772019.2016.1194575

Sánchez-García A, Peñalver E, Delclòs X, Engel MS (2018) Mating and aggregative behaviors among basal hexapods in the Early Cretaceous. Plos One 13:e0191669. https://doi.org/10.1371/journal.pone.0191669

Schloss CA, Nuñez TA, Lawler JJ (2012) Dispersal will limit ability of mammals to track climate change in the Western Hemisphere. Proc Natl Acad Sci USA 109:8606-8611. https://doi.org/10.1073/pnas.1116791109

Schuppenhauer MM, Lehmitz R, Xylander WER (2019) Slow-moving soil organisms on a water highway: aquatic dispersal and survival potential of Oribatida and Collembola in running water. Mov Ecol 7:20. https://doi.org/10.1186/s40462-019-0165-5

Scourfield DJ (1940) The oldest known fossil insect. Nature 145:799-801. https://doi.org/10.1038/145799a0

Sechi V, D'Annibale A, Maraldo K, Johansen A, Bossi R, Jensen J, Krogh PH (2014) Species composition of a soil invertebrate multi-species test system determines the level of ecotoxicity. Environ Pollut 184:586-596. https://doi.org/10.1016/j.envpol.2013.10.008

Sgardelis SP, Sarkar S, Asikidis, MD, Cancela da Fonseca JP, Stamou, GP (1993) Phenological patterns of soil microarthropods from three climate regions. Eur J Soil Biol 29:49-57

Shaw P (2013) The use of inert pads to study the Collembola of suspended soils. Soil Organisms 85:69-74

Shaw P (2015) How high do Collembola climb? Studies of vertical migration in arboreal Collembola. Soil Organisms 87:229-235 
655

656

657

658

659

660

661

662

663

664

665

666

667

668

669

670

671

672

673

674

675

676

677

678

679

680

681

682

Shaw P, Faria C, Emerson B (2013) Updating taxonomic biogeography in the light of new methods: examples from Collembola. Soil Organisms 85:161-170

Siepel H (1994) Life-history tactics of soil microarthropods. Biol Fertil Soils 18:263-278. https://doi.org/10.1007/BF00570628

Sjögren M (1997) Dispersal rates of Collembola in metal polluted soil. Pedobiologia 41:506-513

Szabó B, Lang Z, Bakonyi G, Mariën J, Roelofs D, Van Gestel CAM, Seres A (2019) Transgenerational and multigenerational stress gene responses to the insecticide etofenprox in Folsomia candida (Collembola). Ecotox Environ Safety 175:181-191. https://doi.org/10.1016/j.ecoenv.2019.03.052

Takeda H (1987) Dynamics and maintenance of collembolan community structure in a forest soil system. Res Pop Ecol 29:291-346. https://doi.org/10.1007/BF02538892

Tamm JC (1986) Temperature-controlled under-water egg dormancy and postflood hatching in Isotoma viridis (Collembola) as forms of adaptation to annual long-term flooding. Oecologia 68:241-245. https://doi.org/10.1007/BF00384794

Templeton AR (1980) The theory of speciation via the founder principle. Genetics 94:1011-1038

Thompson PL, Fronhofer EA (2019) The conflict between adaptation and dispersal for maintaining biodiversity in changing environments. Proc Natl Acad Sci USA 116:21061-21067. https://doi.org/10.1073/pnas.1911796116

Timmermans MJTN, Ellers J, Mariën J, Verhoef SC, Ferwerda EB, Van Straalen NM (2005) Genetic structure in Orchesella cincta (Collembola): strong subdivision of European populations inferred from mtDNA and AFLP markers. Mol Ecol 14:2017-2024. https://doi.org/10.1111/j.1365-294X.2005.02548.x

Timmermans MJTN, Ellers J, Van Straalen NM (2007) Allelic diversity of metallothionein in Orchesella cincta (L.): traces of natural selection by environmental pollution. Heredity 98:311-319. https://doi.org/10.1038/sj.hdy.6800942

Timmermans MJTN, Mariën J, Roelofs D, Van Straalen NM, Ellers J (2004) Evidence for multiple origins of Wolbachia infection in springtails. Pedobiologia 48:469-475. https://doi.org/10.1016/j.pedobi.2004.07.008 
683

684

685

686

687

688

689

690

691

692

693

694

695

696

697

698

699

700

701

702

703

704

705

706

707

708

709

710

Tully T, D’Haese CA, Richard M, Ferrière R (2006) Two major evolutionary lineages revealed by molecular phylogeny in the parthenogenetic Collembola species Folsomia candida. Pedobiologia 50:95-104. https://doi.org/10.1016/j.pedobi.2005.11.003

Tully T, Potapov M (2015) Intraspecific phenotypic variation and morphological divergence of strains of Folsomia candida (Willem) (Collembola: Isotomidae), the "standard" test springtail. PLoS One 10:e0136047. https://doi.org/10.1371/journal.pone.0136047

Vandekerckhove TTM, Watteyne S, Willems A, Swings JG, Mertens J, Gillis M (1999) Phylogenetic analysis of the 16S rDNA of the cytoplasmic bacterium Wolbachia from the novel host Folsomia candida (Hexapoda, Collembola) and its implications for wolbachial taxonomy. FEMS Microbiol Lett 180:279-286. https://doi.org/10.1111/j.1574-6968.1999.tb08807.x

Van der Wurff AWG, Gols R, Ernsting G, Van Straalen NM (2005) Population genetic structure of Orchesella cincta (Collembola; Hexapoda) in NW Europe, as revealed by microsatellite markers

Van der Wurff AWG, Isaaks JA, Ernsting G, Van Straalen NM (2003) Population substructures in the soil invertebrate Orchesella cincta, as revealed by microsatellite and TE-AFLP markers. Mol Ecol 12:1349-1359. https://doi.org/10.1046/j.1365-294X.2003.01811.x

Van Dooremalen C, Berg MP, Ellers J (2013) Acclimation responses to temperature vary with vertical stratification: implications for vulnerability of soil-dwelling species to extreme temperature events. Global Change Biol 19:975-984. https://doi.org/10.1111/gcb.12081

Vanhee B, Salmon S, Devigne C, Leprêtre A, Deharveng L, Ponge JF (2017) The 'terril' effect: coal mine spoil tips select for collembolan functional traits in post-mining landscapes of northern France. Appl Soil Ecol 121:90-101. https://doi.org/10.1016/j.apsoil.2017.09.027

Van Straalen NM, Burghouts TBA, Doornhof MJ, Groot GM, Janssen MPM, Joosse ENG, Van Meerendonk JH, Theeuwen TPJJ, Verhoef HA, Zoomer HR (1987) Efficiency of lead and cadmium excretion in populations of Orchesella cincta (Collembola) from various contaminated forest soils. J Appl Ecol 24:953-968. https://doi.org/10.2307/2403992

Verhoef HA, Nagelkerke CJ (1977) Formation and ecological significance of aggregations in Collembola: an experimental study. Oecologia 31:215-226. https://doi.org/10.1007/BF00346922

Waldorf ES (1974) Sex pheromone in the springtail, Sinella curviseta. Environ Entomol 3:916-918. https://doi.org/10.1093/ee/3.6.916 
714 Weider LJ (1993) A test of the "general-purpose" genotype hypothesis: differential tolerance to thermal and salinity stress among Daphnia clones. Evolution 47:965-969. https://doi.org/10.1111/j.1558-5646.1993.tb01251.x

Wertheim B, Van Baalen EJA, Dicke M, Vet LEM (2005) Pheromone-mediated aggregation in nonsocial arthropods: an evolutionary ecological perspective. Ann Rev Entomol 50:321-346. https://doi.org/10.1146/annurev.ento.49.061802.123329

Williams GC (2019) Adaptation and Natural Selection: A Critique of Some Current Evolutionary Thought. Princeton University Press, Princeton.

Wright SJ, Muller-Landau HC, Schipper J (2009) The future of tropical species on a warmer planet. Conserv Biol 23:1418-1426. https://doi.org/10.1111/j.1523-1739.2009.01337.x

Yin R, Gruss I, Eisenhauer N, Kardol P, Thakur MP, Schmidt A, Xu ZF, Siebert J, Zhang CS, Wu GL, Schädler M (2019) Land use modulates the effects of climate change on density but not community composition of Collembola. Soil Biol Biochem 138:107598. https://doi.org/10.1016/j.soilbio.2019.107598

Zimdars B, Dunger W (2000) Different methods for the evaluation of species of the genus Mesaphorura (Collembola, Tullbergiinae). Pedobiologia 44:240-247. https://doi.org/10.1078/S0031-4056(04)70044-X

Zizzari ZV, Ellers J (2014) Rapid shift in thermal resistance between generations through maternal heat exposure. Oikos 123:1365-1370. https://doi.org/10.1111/oik.01496

Zizzari ZV, Engl T, Lorenz S, Van Straalen NM, Ellers J, Groot AT (2017) Love at first sniff: a spermatophore-associated pheromone mediates partner attraction in a collembolan species. Anim Behav 124:221-227. https://doi.org/10.1016/j.anbehav.2016.12.015 


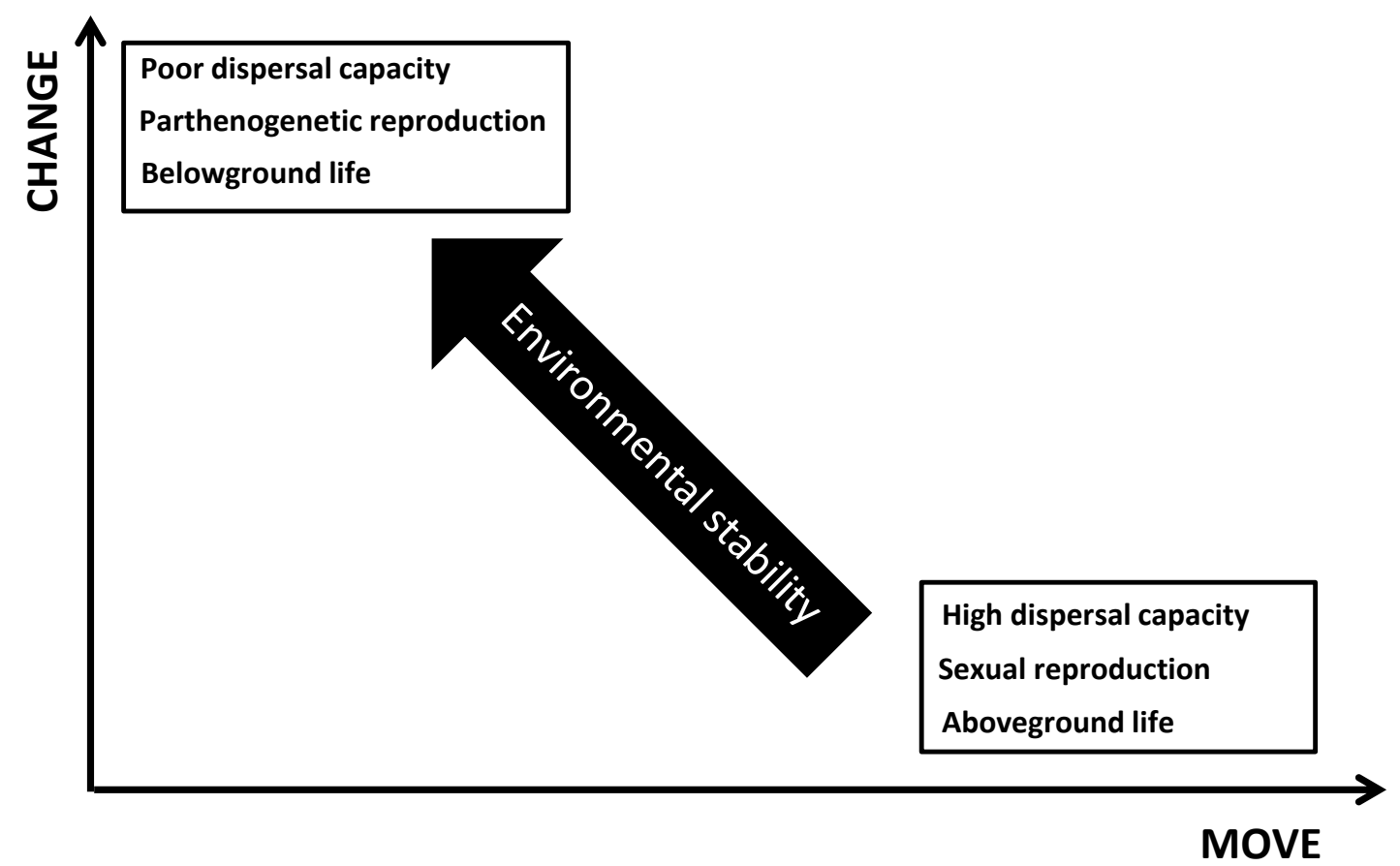

737

738 Fig. 1. Sketch diagram showing main collembolan attributes linked to two opposite strategies face to environmental hazards 